\title{
SCLEROSTOME PARASITES OF THE HORSE IN ENGLAND.
}

I. THE GENERA TRIODONTOPHORUS AND OESOPHAGODONTUS.

\author{
By CHARLES L. BOULENGER, M.A., D.Sc., \\ Reader in Helminthology, University of Birmingham. \\ (From the Research Laboratory in Agricultural Zoology, \\ University of Birmingham.)
}

(With Plate XXII and 7 Text-figures.)

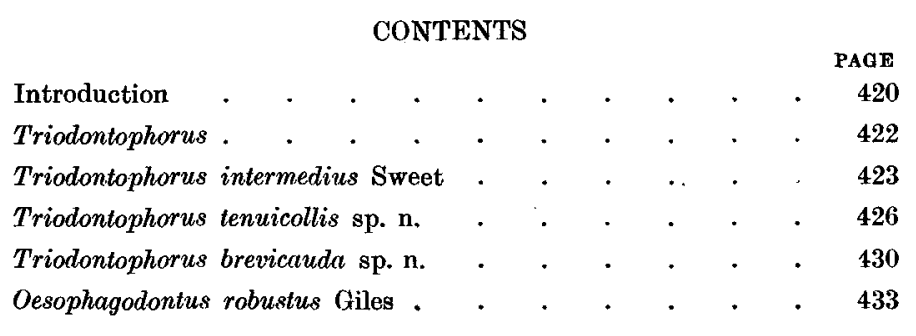

\section{INTRODUCTION.}

SINCE the appearance in 1901 of Looss' important monograph on the Sclerostomes of Horses and Donkeys in Egypt a much greater interest has been shown in the presence of these and allied Nematodes in other parts of the world, but, although nearly fifteen years have elapsed since that publication, very little addition has been made to our knowledge of this branch of helminthology. 
Railliet and Henry (1902) were the first to show that the three species of Sclerostomum, as well as representatives of the three other genera established by Looss (Cylichnostomum, Triodontophorus and Gyalocephalus), were of common occurrence in European countries and were abundantly represented in the Alfort collections. Leiper's (1910) list of species found in horses from the London area shows that the same genera occur in this country and we are indebted to the researches of Sweet (1909) and Gough (1908) for a few records of equine Sclerostomes in Australia and South Africa, respectively.

Much remains, however, to be done on this subject especially in England where the parasites of horses have not attracted the attention of helminthologists during recent years.

My interest in the subject was aroused in the spring of 1915 when the attention of the Birmingham Research Department, under Professor F. W. Gamble, F.R.S. ${ }^{1}$, was directed to important outbreaks of Sclerostomiasis in horses in certain districts of Worcestershire. Thanks to the kindness of Mr J. A. Gold, M.R.C.V.S., of Redditch, I have been able to examine a number of infected animals and to assist in postmortem investigations of cases which have had a fatal termination; specimens were also obtained from "knackers" in different parts of the Birmingham area and $\mathrm{I}$ am also indebted to $\mathrm{Mr}$ Brailsford of the Birmingham Health Department for some interesting material.

Sclerostomes are undoubtedly responsible for a considerable amount of damage to horses in this country; before any serious measures can be taken for the prevention and eradication of the disease it is absolutely essential that a good deal of information be obtained with regard to the distribution, frequency of occurrence and life-histories of the different forms connected with Sclerostomiasis. Such information is gradually being obtained; in view however of the large number of species met with during the course of my investigations it has been thought advisable to publish a systematic account of the different Sclerostomes observed before proceeding to any discussion of their bionomics or pathogenicity.

The present paper deals exclusively with the two genera Triodontophorus Looss and Oesophagodontus Railliet and Henry; of the former little seems known in England, whilst the latter has previously been observed in India and Burmah only.

1 I wish to take this opportunity of expressing my thanks to Professor Gamble for suggesting this line of research and for his assistance in obtaining material from various sources. 


\section{Genus Triodontophorus Looss 1901.}

Triodontus Looss 1900, non Westwood 1845.

Triodontoporus Railliet and Henry 1902.

The genus Triodontophorus was established by Looss (1901) to include two very characteristic Sclerostomes met with in Egypt, in which the oral capsule contained three peculiarly arranged teeth arising from its floor and directed towards the mouth opening. Two species, $T$. serratus and $T$. minor, were obtained from horses and donkeys.

Railliet and Henry (1902) announced the discovery of the genus in France, but do not seem to have identified the species observed by them. T. serratus was later recorded by $\nabla$. Linstow (1904) and Leiper (1910) from horses in India and England respectively.

A third species, $T$. intermedius, was described by Sweet (1909) from the horse in Victoria, Australia.

In addition to these three forms from the Equidae, a fourth species, T. deminutus, has been described from man in the tropics by Railliet and Henry (1905); these authors were able to show later $(1909,1912)$ that, in spite of certain superficial resemblances, especially in the structure of the oral capsule, to Looss' genus, this form belongs to a distinct genus, named by them Ternidens; it is more closely related to the Oesophagostomeae than to the Cylicostomeae in which Triodontophorus is included.

The section Cylicostomeae of the sub-family Strongylinae ${ }^{1}$ (Sclerostominae) is defined by Railliet and Henry (1912) as follows:

"Bourse caudale à côtes antérieures fendues, moyennes dédoublées, postérieures externes naissant isolément, postérieures tridigitées. Vulve proche de l'anus; utérus à branches parallèles. Parasites du tube digestif."

Three species of Triodontophorus were found in horses in the Birmingham district, of which none could be assigned to either of Looss' species; one species is referred to $T$. intermedius Sweet, the two others are described as new.

The genus Triodontophorus can be defined as follows:

Cylicostomeae: Cuticle transversely striated. Mouth capsule large, with three radially-arranged teeth projecting forward into its cavity

1 Railliet and Henry (1912) give the following definition of this sub-family of the Strongylidae: "Capsule buccale bien développée. CEufs en segmentation au moment de la ponte. Presque toujours embryon rhabditiforme et développement direct." 
from the oesophageal funnel. Six head-papillae. The anterior leafcrown consists of numerous leaf-like elements springing from the internal surface of the well-developed mouth-collar; the posterior leaf-crown is represented by a ring of low septa-like projections, corresponding in number and distribution to the leaves of the anterior crown. The dorsal gutter of the oesophageal gland is well developed and terminates at the anterior border of the mouth capsule. The bursa of the male has a finely denticulated border, the median lobe is prominent. A dermal collar partly or completely surrounds the genital cone and the prebursal papillae are greatly elongated. The spicules are long and terminate in small hooks. The female opening is in the posterior region of the body.

\section{Triodontophorus intermedius Sweet 1909.}

As mentioned above this species was described by Sweet in 1909 from three female specimens preserved in the Biological Museum of the University of Melbourne. The types were from Horsham, Victoria, and were labelled "Horse: stomach (and intestines?)", probably in error, as from our knowledge of allied species it seems almost certain that they can only have been obtained from some part of the large intestine.

Whilst commenting on the fact that this species in some respects combines the characters of $T$. serratus and $T$. minor, Sweet remarks "one is tempted at first sight from some of the linear proportions to regard it as an immature form of $\boldsymbol{T}$. serratus, but that is seen to be out of the question on examination of the reproductive organs, which are fully mature."

Among my material from the Redditch district of Worcestershire were a number of worms which I, also, originally took to be specimens of $T$. serratus; more careful examination of these showed that I was dealing with a species, quite distinct from that described by Looss, but agreeing very well with the Australian form, at least as far as the females were concerned. As both sexes were abundantly represented I am able to add considerably to Sweet's diagnosis.

SPECIFIC diagnosis. Triodontophorus: cuticle of the whole body transversely ringed in a similar manner to Looss' type species. The head is not sharply marked off from the rest of the body, its diameter . is $200-260 \mu$. The mouth-collar is high, not depressed near the outer margin as in $T$. serratus and $T$. minor, on the contrary it appears approximately circular when seen in profile (Text-fig. $2 \mathrm{~A}$ ). The external 
leaf-crown consists of about forty-eight leaves, an equal number of small plates project from their bases into the cavity of the mouth capsule and constitute the internal leaf-crown. The mouth capsule is a little broader than high, measuring $150-180 \mu$ in maximum breadth and $100-130 \mu$ in length. The three large teeth have their anterior margins denticulated as in T. serratus (Text-fig. $2 \mathrm{~A}$ ).

The oesophagus measures $0.97-1 \cdot 3 \mathrm{~mm}$. in length. A pair of cervical papillae are situated at about the level of the excretory opening, 620$700 \mu$ from the anterior extremity.

Female: $16 \cdot 5-18.7 \mathrm{~mm}$. in length. The body attains a maximum thickness of $650-750 \mu$ near the middle, this becomes reduced to 400 $500 \mu$ at the level of the base of the oesophagus. The "tail region" is elongated but not to quite the same extent as in T. serratus, the distance of the vulva being $1.45-1.7 \mathrm{~mm}$., that of the anus $450 \mu$ from the posterior extremity ( $f f$. Text-fig. $3 \mathrm{~A}$ ). The body has a diameter of about $450 \mu$ at the level of the vulva, behind this point it tapers rapidly giving the whole tail region a very pointed appearance when viewed under a low magnification (Text-fig. $1 \mathrm{~A}$ ). The eggs are considerably smaller than those of $T$. serratus as figured by Looss ${ }^{1}$, they measure $90-100 \mu$ in length and $40-50 \mu$ in breadth.

Male: $145-15.5 \mathrm{~mm}$. in length, about $650 \mu$ in thickness near the middle of the body and $400-450 \mu$ at the base of the bursa. The bursa has an approximate width of $800 \mu$, the median lobe is short and wide and is similar to that of $T$. serratus; as in the latter species the dermal collar of the genital cone covers its anterior face only. The prebursal papillae and the rays of the bursa also very closely resemble those of T. serratus (Text-fig. $4 \mathrm{~A}$ ). As in Looss' species the spicules are very thick and provided with relatively small, strongly recurved hooks (Text-fig. $6 \mathrm{~A}$ ); they differ from those of T. serratus in the possession of stout barbs projecting backwards from the shafts a short distance behind the hooks. The spicules are enclosed in a delicate, finely striated sheath.

$T$. intermedius was found on several occasions in company with other Sclerostomes, both in the colon and caecum. Although many specimens were collected it never occurred in sufficient numbers to be suspected of causing symptoms of Sclerostomiasis.

I In his monograph (1901) Looss omits the measurements of the eggs; he, however, figures those of both species of Triodontophorus in his memoir on Anchylostomum duodenale (1911), his figures are $\times 310$ which gives a length of about $130 \mu$ in 'T'. serrotus and $97 \mu$ in T. minor. 
C. L. Boulenger

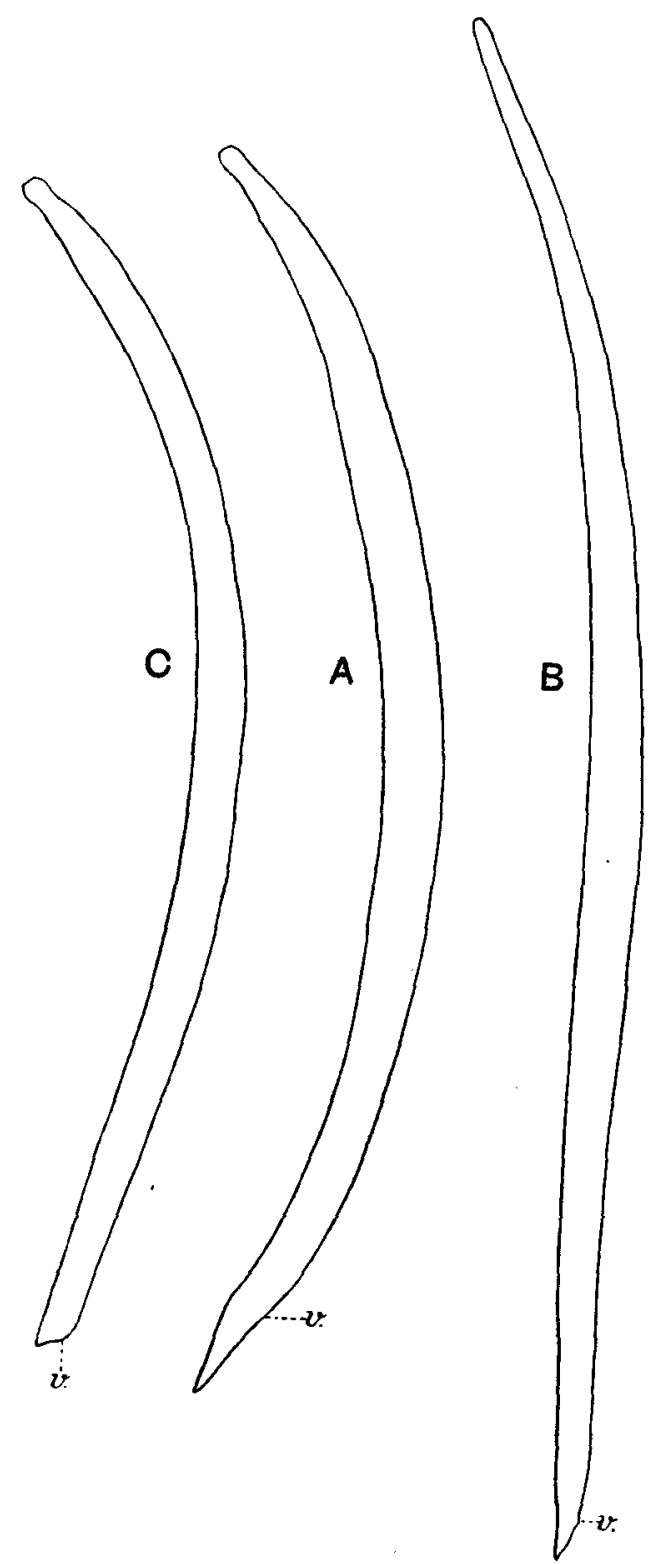

Fig. 1. Outline drawings of the females of three species of Triodontophorus, viewed from right side. A. T. intermedius Sweet. B. T. tenuicollis sp. n. C. T. brevicauda sp. $n . \quad v$. shows position of vulva. $\times 8$. 
$T$. intermedius is certainly very closely allied to $T$. serratus, it can however be readily distinguished from that species by its smaller size, the shape of the mouth-collar, the position of the vulva and the size of the eggs in the females, and by the character of the spicules in the males.

\section{Triodontophorus tenuicollis sp. $n$.}

Specific Diagnosis. Triodontophorus: the body attains its greatest thickness near the middle and tapers markedly towards both extremities; the thickness at the level of the base of the oesophagus is less than half the maximum thickness. The cuticle is transversely ringed, near the middle and at the posterior extremity these cuticular rings are much as in the other species of the genus, in the narrow anterior region they are, however, much accentuated and modified in such a way as to give the body-margins a coarsely serrated appearance (Text-fig. $2 \mathrm{~B}$ ).

The head is not separated from the body and is smaller than in the other species, its diameter varies from $150-200 \mu$. The mouth-collar is depressed as in T. minor Looss; the elements of the external and internal leaf-crowns number 40-44. Owing to the small size of the head the dimensions of the mouth capsule are also much reduced, it has a breadth of $110-140 \mu$ and a maximum length of $70-90 \mu$. The anterior margins of the teeth are provided with sharp denticulations as in $T$. serratus and T. intermedius (Text-fig. $2 \mathrm{~B}$ ).

The oesophagus is rather short, measuring $620-900 \mu$. The excretory pore is at about the same level as the cervical papillae, $680-750 \mu$ from the anterior end.

Female: $16-19.5 \mathrm{~mm}$. in length. The maximum thickness near the middle of the body is $700-770 \mu$, whilst opposite the termination of the oesophagus it measures only $280-300 \mu$. The body also tapers considerably towards the posterior end and the thickness at the level of the vulva is considerably less than in the other species, being only $250-300 \mu$. The tail region is short, the vulva being situated $460-560 \mu$ from the posterior extremity. The anus is about $120 \mu$ from the end of the body (Text-fig. $3 \mathrm{~B}$ ).

The eggs are indistinguishable from those of the preceding species.

Male: $13 \cdot 5-19 \mathrm{~mm}$. in length; the greatest thickness near the middle is $450-650 \mu$, at the termination of the oesophagus $230-250 \mu$. The body also tapers towards the bursa, the breadth at the base of that structure being $280-350 \mu$. 
The bursa has about the same width as that of $T$. intermedius and is also provided with a short median lobe, the latter, however, is more

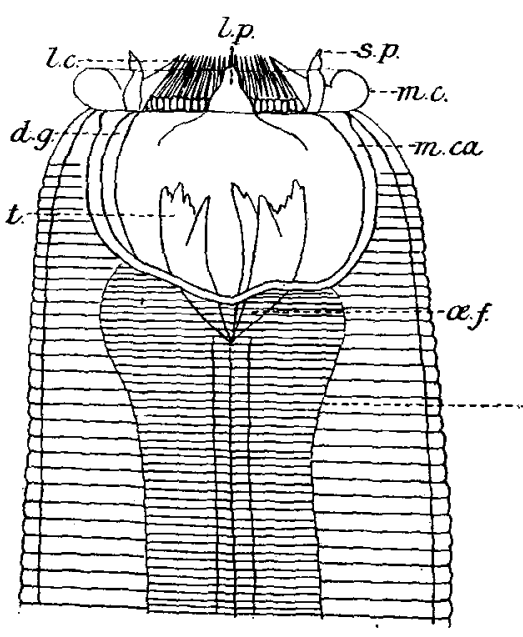

A

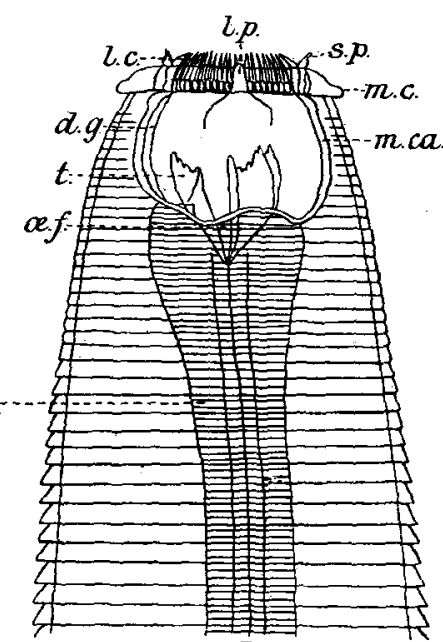

B

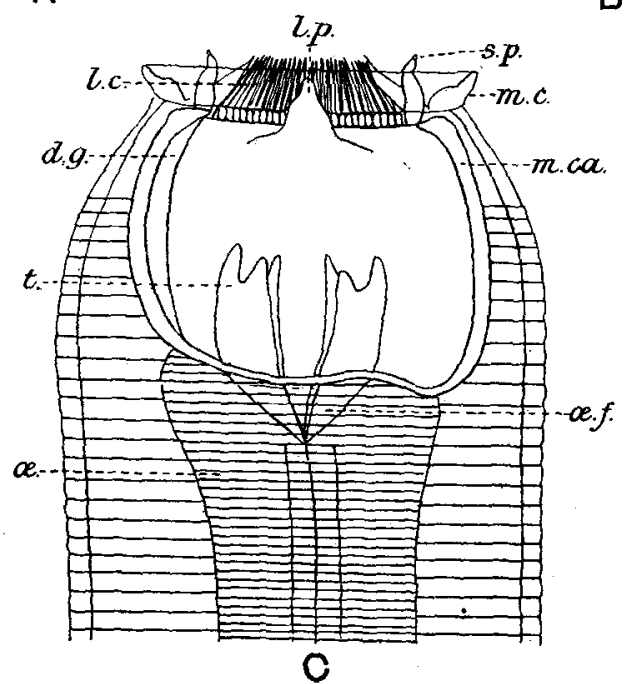

Fig. 2. Anterior extremities of the three species of Triodontophorus, viewed from right side. A. T. intermedius Sweet. B. T. tenuicollis sp. n. C. T. brevicauda sp. $\mathbf{n}$. l.p. lateral head papilla. m.c. mouth-collar. m.ca. mouth capsule. oe. oesophagus. oe.f. oesophageal funnel. s.p. sub-median head-papilla. d.g. dorsal gutter of oesophageal gland. l.c. leaf-crown. $t$. tooth. $\times 150$.

sharply marked off from the lateral lobes (Text-fig. $5 \mathrm{~B}$ ) and is also carried in a somewhat different manner; when seen in a side view 
(Text-fig. $4 \mathrm{~B}$ ) it appears almost at right angles to the longitudinal axis of the body. The dermal collar is enormously developed and completely surrounds the genital cone, in consequence the prebursal papillae
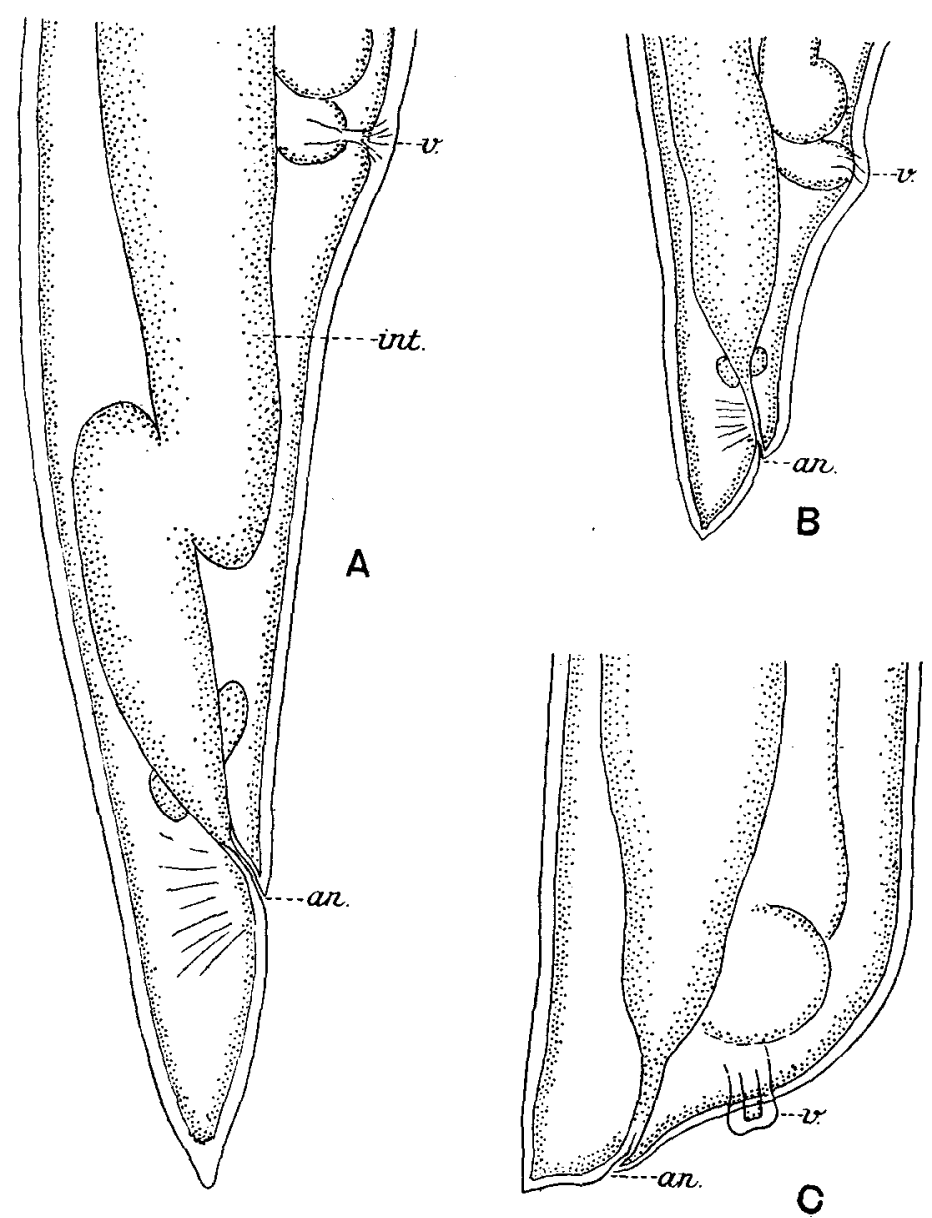

Fig. 3. Posterior extremities of females, viewed from right side. A. T. inlermedius Sweet. B. T. tenuicollis sp. n. C. T. brevicauda sp. n. an. anus. int. intestine. v. vulva. $\times 75$.

have become greatly elongated. The rays of the bursa resemble those of $T$. intermedius, the tips of the ventral rays are however slightly more divergent. 
The spicules are very slender and have characteristic terminations (Text-fig. $6 \mathrm{~B}$ ), the hooks being feebly developed and forming wide angles with the shafts.

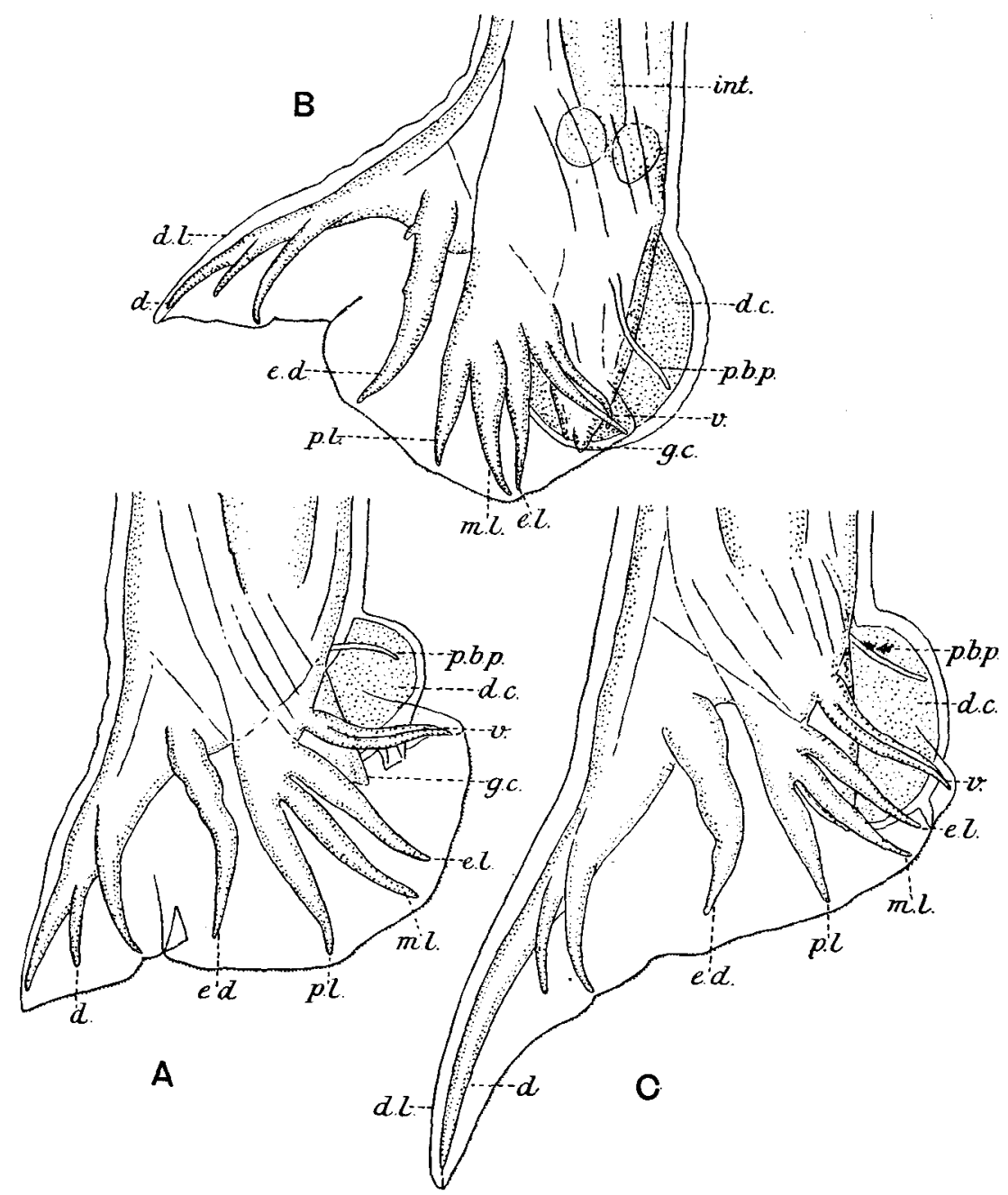

Fig. 4. Male genital bursae viewed from right side. A. T. intermedius Sweet. B. T. tenuicollis sp. n. C. T. brevicauda sp. n. d. dorsal rays. d.c. dermal collar of genital cone. d.l. dorsal lobe. e.d. externo-dorsal ray. e.l. externo-lateral ray g.c. genital cone. int. intestine. m.l. medio-lateral ray, p.b.p. prebursal papilia. p.l. postero-lateral ray. v. ventral rays. $\times 75$. 
This species is by far the most abundant of the three observed in the Birmingham district, it was found on several occasions in enormous numbers in the colon and caecum in horses suffering from intestinal and other troubles. When alive $T$. tenuicollis is semi-transparent of a whitish colour, tinged with a blood-red pigment; the latter is often restricted to the anterior end and in this position is most brilliant, the coloured extremity contrasting vividly with the rest of the body. The pigment lies partly in the body-cavity and therefore cannot be considered simply as blood derived from the host ${ }^{1}$.

\section{Triodontophorus brevicauda sp. n.}

Specific Diagnosis. Triodontophorus: the body appears rather blunt owing to the somewhat thick extremities. The head is broad $(270-325 \mu)$ and separated from the body by a gentle constriction behind the mouth capsule. The mouth-collar is very characteristic, being high and erect, attaining its greatest breadth anteriorly so as to appear separated from the rest of the head by a deep constriction (Text-fig. 2 C). Owing to the large size of the head the elements of the leaf-crowns are more numerous than in the preceding species, the average number being 60 .

The mouth capsule is large, appearing nearly as long as broad and measuring $160-210 \mu$ by $200-250 \mu$. The anterior edges of the teeth are not denticulated and present a similar appearance to those of T. minor Looss (Text-fig. $2 \mathrm{C}$ ). The cuticle of the whole body is transversely ringed.

The oesophagus varies in length from 0.9 to $1.4 \mathrm{~mm}$. The cervical papillae are, as in the other species, situated close to the level of the excretory pore, $730-880 \mu$ from the anterior end.

Female: 16-17 mm. in length. The body has a thickness of 670 $700 \mu$ in the middle and tapers gently towards the anterior extremity, the thickness at the level of the oesophageal termination being about $500 \mu$. The shape of the posterior extremity is very characteristic; the anus is only $100-130 \mu$ from the end and the vulva is immediately in front of it (Text-fig. $3 \mathrm{C}$ ), the distance between the two openings averaging $170 \mu$. The body has a breadth of about $420 \mu$ just in front of the vulva and tapers so suddenly behind this point that the whole

1 Cf. Looss' remarks on the coloration of Anchylostoma duodenale (1905, p. 32), also Boulenger (1915, p. 137). 
tail region appears obliquely truncated when seen under a low magnification (Text-fig. $1 \mathrm{C}$ ).

The eggs as in the preceding species measure $90-100 \mu$ in length.

Male: $13.5-14 \mathrm{~mm}$. in length. The breadth in the middle of the body is $600-650 \mu$, at the base of the bursa $400-460 \mu$. The bursa is characterised by the greatly elongated median lobe (Text-figs. 4 and $5 \mathrm{C}$ )

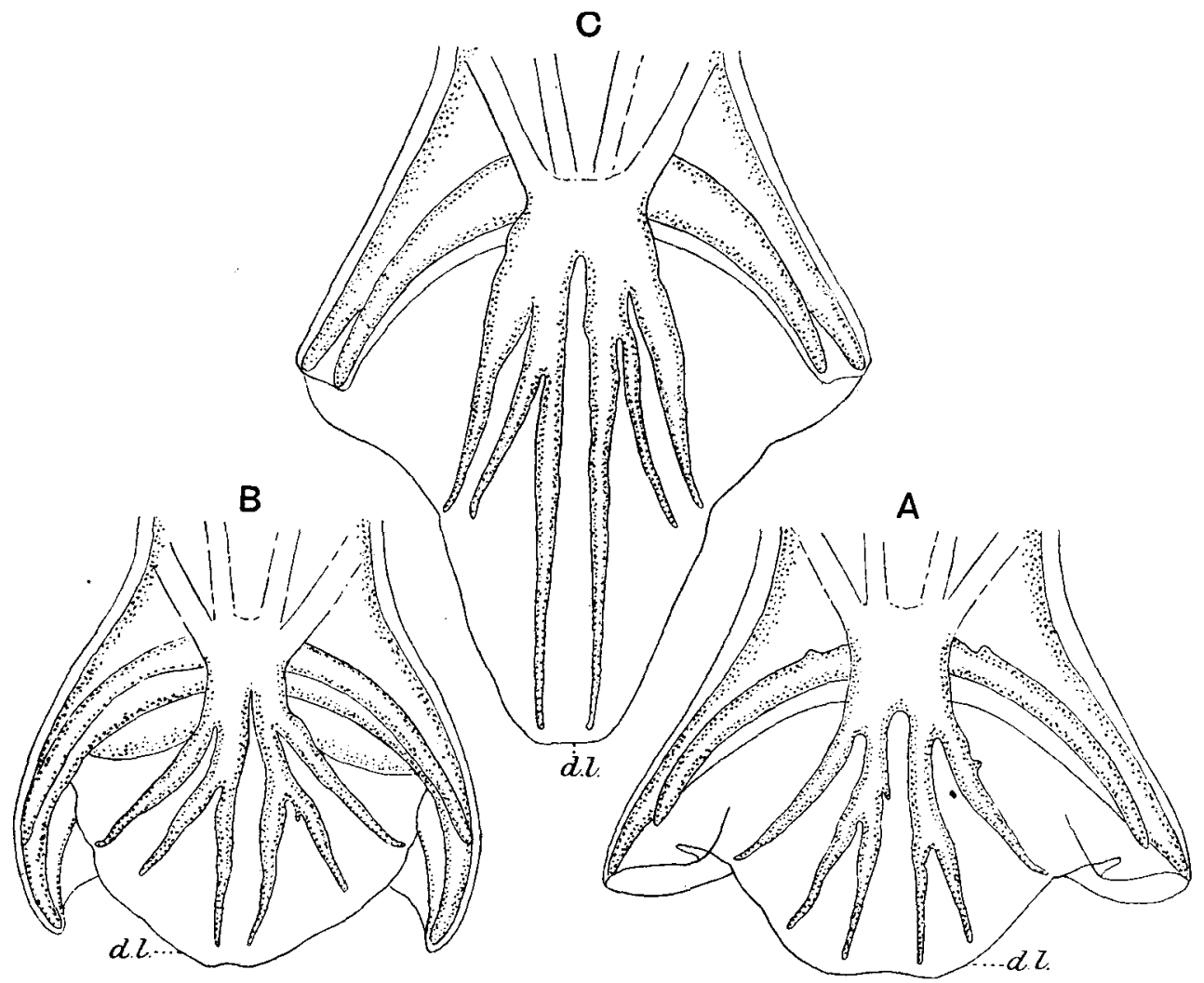

Fig. 5. Male genital bursae viewed from dorsal side. A. T. intermedius Sweet. B. T. tenuicollis sp. n. C. T. brevicauda sp. n. d.l. dorsal lobe with six dorsal rays. $\times 75$.

and the corresponding length of the dorsal rays which measure up to $750 \mu$. As in $T$. minor the dermal collar completely surrounds the genital cone (Text-fig. $4 \mathrm{C}$ ), it is however not developed to the same extent as in $T$. tenuicollis and the prebursal papillae are consequently a little shorter than in that species. 
The spicules are slender (Text-fig. $6 \mathrm{C}$ ), the hooks are more strongly recurved than in $T$. tenuicollis and are further characterised by the peculiar hammer-shaped "barbs" at their junctions with the shafts.

T. brevicauda was found in the colon and caecum on several occasions, like $T$. intermedius it never occurred in large numbers. The species is obviously closely allied to $T$. minor Looss; it can, however, be readily distinguished by the shape of the mouth-collar, by the peculiar structure of the tail region in the females, and by the characters of the spicules in the males.
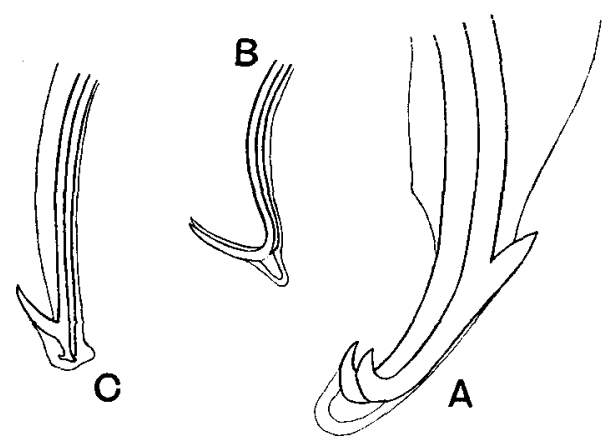

Fig. 6. Terminal portions of spicules. A. T. intermedius Sweet. B. T. tenuicollis sp. n:

C. T. brevicauda sp. n. $\times 375$.

It will be seen from the diagnoses given above that, apart from size, the various species of Triodontophorus are distinguishable by the combinations of various well-marked characters, the most important of which are: in both sexes, the shape of mouth-collar and the shape and size of the oral capsule; in the females, the shape of the "tail" and the distance of the vulva from the posterior extremity; in the males, the form and size of the dorsal lobe of the bursa and the spicules. The more important of the distinctive characters are tabulated on the opposite page; in the case of $T$. serratus and $T$. minor the various measurements have been obtained from Looss' monograph (1901), either from the text or the plates. 


\section{TRIODONTOPHORUS.}

\begin{tabular}{|c|c|c|c|c|c|}
\hline & T. servatus & T. intermedius & T. tenuicollis & T. brevicauta & T. minor \\
\hline $\begin{array}{l}\text { Length of female } \\
\text { Length of male } \\
\text { Mouth collar ... }\end{array}$ & $\begin{array}{l}25 \mathrm{~mm} . \\
18 \mathrm{~mm} . \\
\text { Slightly } \\
\text { depressed } \\
\text { at margin }\end{array}$ & $\begin{array}{c}16 \cdot 5-18.7 \mathrm{~mm} \\
14.5-15.5 \mathrm{~mm} \\
\text { Circular in } \\
\text { profile }\end{array}$ & $\begin{array}{l}16-19 \cdot 5 \mathrm{~mm} . \\
13 \cdot 5-19 \mathrm{~mm} . \\
\text { Depressed at } \\
\text { margin }\end{array}$ & $\begin{array}{c}16-17 \mathrm{~mm} . \\
\text { 13.5-14 mm. } \\
\text { Erect }\end{array}$ & $\begin{array}{l}14 \mathrm{~mm} . \\
13 \mathrm{~mm} . \\
\text { Depressed } \\
\text { at margin }\end{array}$ \\
\hline $\begin{array}{l}\text { Elements of leaf- } \\
\text { crown } \\
\text { Mouth capsule: }\end{array}$ & $52-55$ & 48 & $40-44$ & 60 & $44-49$ \\
\hline $\begin{array}{c}\text { Height } \\
\text { Breadth } \ldots \\
\text { Capsule teeth :... }\end{array}$ & $\begin{array}{l}0.12 \mathrm{~mm} \text {. } \\
0.18 \mathrm{~mm} \text {. }\end{array}$ & $\begin{array}{c}0 \cdot 1-0.13 \mathrm{~mm} . \\
0.15-0.18 \mathrm{~mm} .\end{array}$ & $\begin{array}{l}0.07-0.09 \mathrm{~mm} . \\
0.11-0.14 \mathrm{~mm} .\end{array}$ & $\begin{array}{c}0.16-0.21 \mathrm{~mm} . \\
0.2-0.25 \mathrm{~mm} .\end{array}$ & $\begin{array}{l}0.19 \mathrm{~mm} . \\
0.19 \mathrm{~mm} .\end{array}$ \\
\hline margins $\ldots$ & Denticulated & Denticulated & Denticulated & $\stackrel{\text { Not }}{\text { denticulated }}$ & $\begin{array}{c}\text { Not } \\
\text { denticulated }\end{array}$ \\
\hline $\begin{array}{c}\text { Vulva from post. } \\
\text { end ... }\end{array}$ & $\begin{array}{l}\text { More than } \\
2 \mathrm{~mm} \text {. }\end{array}$ & $1.45-1.7 \mathrm{~mm}$ & $0.46-0.56 \mathrm{~mm}$ & About $0.3 \mathrm{~mm}$. & About $0.7 \mathrm{~mm}$. \\
\hline $\begin{array}{cc}\text { Dorsal lobe of } \\
\text { bursa } & \ldots\end{array}$ & Short & Short & $\begin{array}{l}\text { Short, sharply } \\
\text { marked off } \\
\text { from lateral } \\
\text { lobes }\end{array}$ & Long & I.ong \\
\hline $\begin{array}{l}\text { Dermal collar of } \\
\text { genital cone }\end{array}$ & $\begin{array}{l}\text { Covers anterior } \\
\text { surface }\end{array}$ & $\begin{array}{l}\text { Covers anterior } \\
\text { surface }\end{array}$ & $\begin{array}{l}\text { Completely } \\
\text { surrounds cone }\end{array}$ & $\begin{array}{c}\text { Completely } \\
\text { surrounds cone }\end{array}$ & $\begin{array}{c}\text { Almost } \\
\text { completely } \\
\text { surrounds cone }\end{array}$ \\
\hline $\begin{array}{cr}\text { Spicules } & \ldots \\
& \text { Length }\end{array}$ & $\begin{array}{c}\text { Comparatively } \\
\text { thick } \\
4 \mathrm{~mm} .\end{array}$ & $\begin{array}{c}\text { Comparatively } \\
\text { thick } \\
3.5 \mathrm{~mm} \text {. }\end{array}$ & $1.25 \mathrm{~mm}$. & $1.75 \mathrm{~mm}$. & $1.8 \mathrm{~mm}$. \\
\hline
\end{tabular}

\section{Genus Oesophagodontus Railliet and Henry.}

Oesophagodontus robustus Giles.

Sclerostomum robustum Giles 1892.

Oesophagodontus robustus Railliet and Henry 1902.

This species was described under the name Sclerostomum robustum by Giles (1892), who observed a large number of specimens in horses and mules in Fndia, they occurred in the colon and caecum in company with other worms and were, at least partly, responsible for the severe symptoms of sclerostomiasis exhibited by their hosts.

Although the species has not been rediscovered since that date, it has figured frequently in helminthological literature. Giles' description was published before the old-established genus Sclerostomum was split up by Looss (1900) and, although on most points accurate, for this reason remained incomplete as regards a number of characters now recognised as of systematic importance, the result being a considerable 
divergence of opinion as to the exact position of the worm in modern classifications.

Looss (1900) was inclined to include $S$. robustum in his genus Triodontophorus; Railliet and Henry (1902), however, expressed the opinion that if Giles' description and figures were accurate the parasite could not be included in any of the known genera, and proposed for it the new generic name Oesophagodontus. In a later paper (1912) these authors assign their genus to the sub-family CyLicostomeaE, close to Cylichnostomum.

Material was obtained by me near Redditch in Worcestershire on one occasion only, from the colon of a mare which had died suddenly after showing symptoms of severe sclerostomiasis. About a dozen specimens were collected from among an enormous number of Triodontophorus tenuicollis and Cylichnostomum spp., examination of these showed that Giles' description of the species was on the whole correct; I have, however, been able to add to his account and my observations also show that Railliet and Henry were undoubtedly right in their estimate of the systematic position of this interesting worm.

Specific DIagnosis. The body is stout, tapering only slightly towards the anterior extremity. During life the worms have a brownish colour and the intestine is deeply pigmented, showing through the semi-transparent body-wall.

The cuticle is provided with transverse ridges as in Triodontophorus. The head is separated from the body by a slightly constricted neck and is of considerable breadth, measuring $500-800 \mu$. The mouth-collar is depressed and its oral margin considerably notched so as to present a tuberculated appearance (Plate XXII, fig. 3). As in the genus Cylich nostomum there are anterior and posterior leaf-crowns, each composed of distinct leaf-shaped elements; the leaves of the anterior crown are large and usually number about 18, those of the posterior crown are considerably smaller, they are rather difficult to count, but, as far as I could ascertain, their usual number is about 36 .

As in other Sclerostominae six head papillae are present, two lateral and four sub-median. The lateral papillae are not markedly raised from the surface of the mouth-collar, their bases are rather broad and carry a pair of lateral horn-like processes; a pair of similar but smaller processes are situated near the anterior extremity of each papilla (cf. Plate XXII, fig. 3, L.P.). Each sub-median papilla consists of a slender tactile appendage carried on a basal, wart-like prominence 
of the mouth-collar, this basal region bears in addition a second appendage in the form of a delicate trumpet-shaped process directed externally (Plate XXII, fig. 3, Sm.P.).

The mouth capsule is goblet-shaped, it attains its greatest width of $0 \cdot 32-0 \cdot 47 \mu$ near its anterior margin and narrows considerably posteriorly. Its length varies from $0 \cdot 22-0 \cdot 32 \mu$. The wall of the capsule is comparatively thin except posteriorly where it is greatly thickened in such a manner as to form a hoop-like transverse ridge encircling the base of the mouth capsule, an exaggeration of the conditions prevailing in some of the larger species of Cylichnostomum, e.g. C. elongatum (cf. Plate XXII, fig. 3, M.C.). There is no dorsal gutter, the dorsal oesophageal gland opening at the base of the capsule.

The oesophagus has a length of $1.3-1.7 \mathrm{~mm}$., it is broadest anteriorly, just behind the mouth capsule, and narrows somewhat towards the middle, increasing again in width posteriorly. The oesophageal funnel is well developed and the lining of its triradiate cavity is modified to form three tooth-like structures, which do not however protrude into the mouth capsule; the general structure of the funnel can be considered as an exaggeration of that met with in some species of Cylichnostomum, e.g. C. elongatum (Looss 1901, p. 129). The excretory pore (Plate XXII, fig. 2) and the cervical papillae occupy a position slightly posterior to the nerve-collar, about $1.2 \mathrm{~mm}$. from the anterior end. The cervical papillae are extremely small and difficult to see.

Females: $19-22 \mathrm{~mm}$. in length with a maximum thickness of $1 \cdot 1-1.5 \mathrm{~mm}$. in the middle of the body; this thickness is maintained behind the middle until the level of the vulva which is situated $2 \cdot 8$ $3.7 \mathrm{~mm}$. from the posterior extremity; behind this point the body tapers rapidly to the end forming a pointed tail region (Plate XXII, fig. 4). The anus lies 0.5-0.7 mm. from the posterior end. The extremity of the tail has a rather variable shape according to the degree of contraction, it frequently appears mucronate as described by Giles.

The female genital organs are arranged on the plan common to all the Cylicostomeae, that is to say the two uteri are parallel.

The eggs are large, oval and thin-shelled, they measure $100-130 \mu$ in length by $50-60 \mu$ in breadth. They are laid in the early morula stage (Plate XXII, fig. 7).

Males: $15-16 \mathrm{~mm}$. in length, the body is thickest $(0.95-1 \mathrm{~mm}$.) in the middle decreasing slowly towards the bursa and measuring $0.45-0.5 \mathrm{~mm}$. in width at the base of that organ.

The bursa has a breadth of 0.9 to $1 \mathrm{~mm}$., as described by Giles it is 
peculiar in being bilobed, no trace of a median (dorsal) lobe being present (Text-fig. 7). The margins of the lateral lobes are finely denticulated as in the genus Triodontophorus. The ventral rays are slender and parallel, and of equal size. The medio-lateral ray is a little shorter than the other lateral rays and the postero-lateral is peculiar in possessing a short thick branch arising from near its base and projecting dorsally (Plate XXII, fig. 5, A.P.l.); this extra lateral ray terminates very bluntly, its exact shape and length vary considerably ${ }^{1}$. There is no median dorsal ray, the dorsal rays arising in two groups of four (Text-fig. 7 and Plate XXII, fig. 5). The externo-dorsal is the longest, the three other dorsals being sub-equal, the middle one is, however, a little shorter than the others.

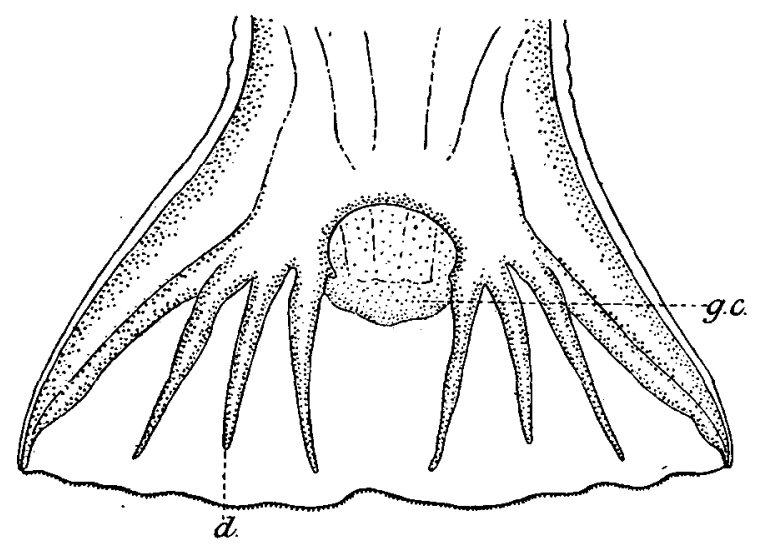

Fig. 7. Dorsal view of bursa of Oesophagodontus robustus Giles. d. dorsal rays. g.c. genital cone.

The genital cone (Plate XXII, fig. 6 and Text-fig. 7) is short and broad, its shape being almost hemispherical; it bears a pair of small lateral papillae, whilst a conical lip-like process is situated medianly, just ventral to the cloacal opening.

As in Triodontophorus and Cylichnostomum the dermal collar (Plate XXII, figs. 5 and 6 ) is well developed, it occupies the ventral aspect of the genital cone only. The prebursal papillae are short.

1 A very similar appendix to the postero-lateral ray is met with in Choniangium epistomum Piana and Stazzi (=Asifia vasifa Lane), a sclerostome parasite of the Indian elephant. Lane (1914) evidently overlooked Giles' species when he wrote "any multiplication of the lateral rays of a bursate nematode appears to be hitherto unknown, and the presence of this feature in the form just described to be unique." Cf. also Railliet, Henry et Bauche (1914). 


\section{L. Boulenger}

The spicules are long and slender, they end bluntly without hook-like terminations, they are enclosed in a finely striated sheath, very conspicuous when the spicules are protruded (Plate XXII, fig. 5, $s p$.).

It will be seen from the above diagnosis that a serious discrepancy exists between it and Giles' account with regard to the position of the vulva; Giles gives the distance between this opening and the anus as about $1 \mathrm{~mm}$. whilst in the specimens examined by me it varied between $2 \cdot 3$ and $3 \mathrm{~mm}$. Giles, however, gives a figure of a pair of the worms in copula in which the position of the female genital opening is certainly further from the posterior extremity than is stated in the text. I think therefore that we may assume that his measurement was given in error.

The eggs in the specimens described by me are also a little smaller than those recorded by Giles, this author gives the egg measurements as $152 \times 82 \mu$; he does not say whether the eggs measured were taken from the maternal uterus or from the faeces of the host; those referred to in my diagnosis are all from the former source, it is a well-known fact that the eggs of various helminths swell considerably after being deposited and it is possible that the discrepancy is due to some such cause.

\section{REFERENCES.}

Bodlenger, C. L. (1915). The Life-history of Nematodirus filicollis Rud., a Nematode Parasite of the Sheep's Intestine. Parasitology, vir. 133.

GILEs, G. M. (1892). On a new Sclerostome from the Large Intestine of Mules. Sci. Mem. of the Medical Officers of the Army of India, Part 7, 25.

Govgr, L. H. (1908). Notes on South African Parasites. Ann. Rep. South African Ass., Grahamstown Meeting, 1.

LANE, C. (1914). Bursate Nematodes from the Indian Elephant. Indian Journ. Med. Res., II. 380.

LeIPER, R. T. (1910). Exhibition of a Series of Specimens of Entozoa. Proc. Zool. Soc. 1910 (1), 147.

Linstow, O. v. (1904). Nematoda in the Collection of the Colombo Museum. Spolia Zeylanica, I. Part 4, 1.

Looss, A. (1900). Notizen zur Helminthologie Egyptens. III. Die Sclerostomen der Pferde und Esel in Egypten. Centralbl. f. Bakteriol. etc. Abt. I. 27, $150-184$.

- (1901). The Sclerostomidae of Horses and Donkeys in Egypt. Rec. Egypt. Govt. School of Med. I. 25. 
Looss, A. (1905). The Anatomy and Life History of Agchylostomum duodenale Dub. Part 1. The Anatomy of the Adult Worm. Rec. Egypt. Govt. School of Med. III. 1.

(1911). The Anatomy and Life History of Agchylostoma duodenale Dub. Part 2. The Development in the Free State. Rec. School of Med. Cairo, IV. 167.

Ratuliet, A. et Henry, A. (1902). Sur les Sclérostomiens des Equidés. C. $r$. Soc. Biol. p. 5.

- (1905). Un nouveau Sclérostomien (Triodontophorus deminutus nov. sp.) parasite de l'Homme. C. r. Soc. Biol. LVIII. 569.

- (1905). Le Triodontophorus deminutus, nouveau Sclérostomien parasite de l'Homme, et la cachéxie africaine. Bull. Mus. d'Hist. nat. 269.

—- (1909). Sur la Classification des Strongylidae. II. Ankylostominae. G. r. Soc. Biol. LXVT. 168.

(1912). Les Oesophagostomiens Parasites de l'Homme. Arch. Parasit. xIv. 562.

Raituiet, A., Henry, A. et Badche, J. (1914). Sur les Helminthes de l'Eléphant d'Asie. Bull. Soc. Pathol. exot. vrr. Nos. 1, 2 et 3.

Sweet, G. (1909). The Endoparasites of Australian Stock and Native Fauna. Part 2. New and unrecorded Species. Proc. R. Soc. Vict. xxi. 454.

\section{EXPLANATION OF PLATE XXII.}

\section{Oesophagodontus robustus Giles.}

Fig. 1. Female, lateral view of a specimen mounted in glycerine, $\times 8$.

Fig. 2. Male, lateral view of a specimen mounted in glycerine, $\times 8$.

Fig. 3. Head, lateral view, $\times 75$.

Fig. 4. Posterior extremity of female body, lateral aspect, $\times 23$.

Fig. 5. Posterior extremity of male body, showing lateral view of the bursa, $\times 75$.

Fig. 6. Ventral view of the genital cone of male, $\times 120$.

Fig. 7. Egg, from maternal uterus, $\times 225$.

\section{INDEX TO LETTERING.}

An. Anus.

A.P.l. Accessory branch of the postero-lateral ray of the bursa.

$B$. Bursa of male.

$D^{1}-D^{3}$. Branches of the dorsal ray of the bursa.

D.C. Dermal collar of the genital cone.

E.d. Externo-dorsal ray of the bursa.

E.l. Externo-lateral ray of the bursa.

E.L.C. External (anterior) leaf-crown.

E.P. Excretory pore. 
PARASITOLOGY, VOL. VIII. NO. 4

PLATE XXII
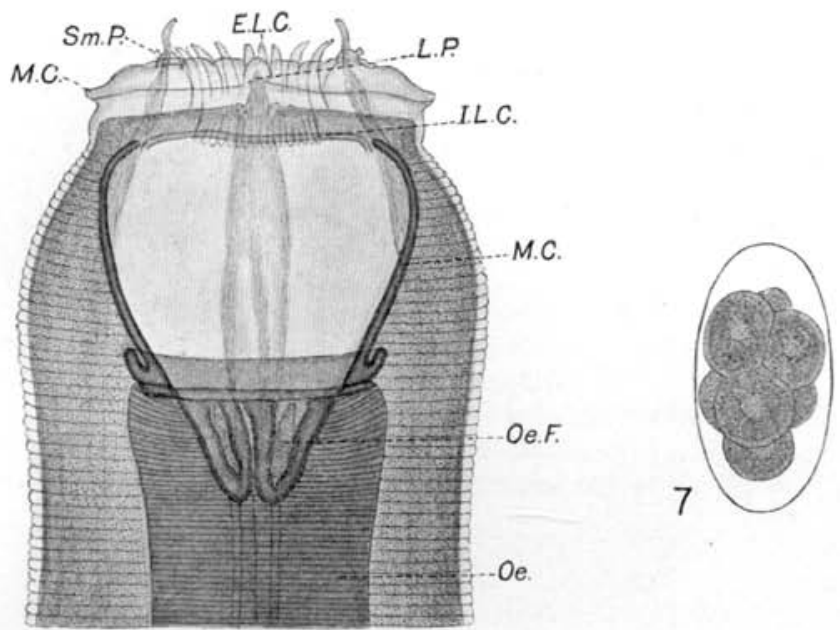

3
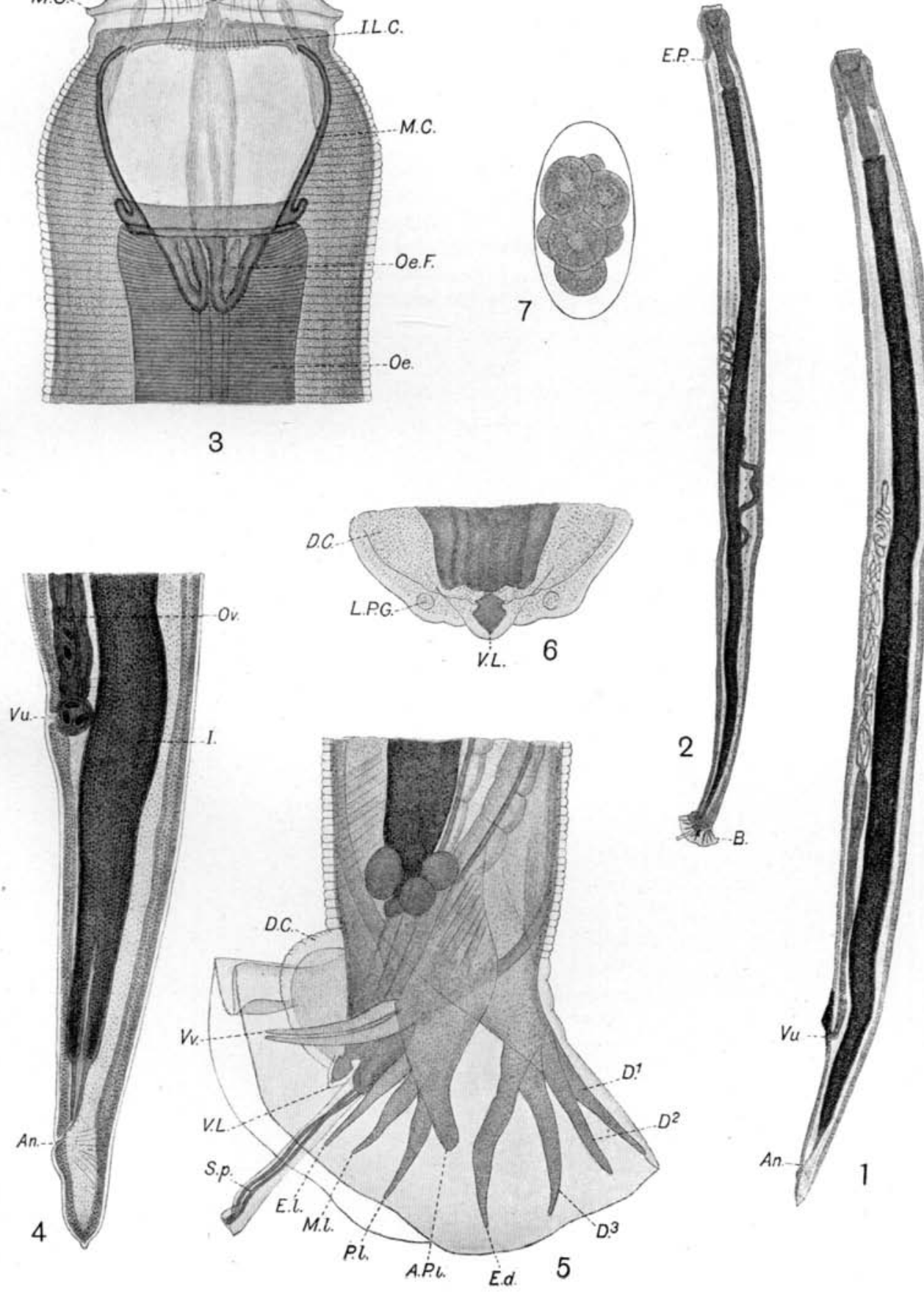


\section{L. Boulenger}

I. Intestine.

I.L.C. Internal (posterior) leaf-crown.

L.P. Lateral papilla of head.

L.P.G. Lateral papilla of the genital cone.

M.C. Mouth-collar.

M.C. Mouth-capsule.

M.l. Medio-lateral ray of the bursa.

Oe. Oesophagus.

Oe.F. Oesophageal funnel.

Ov. Ovijector.

P.l. Postero-lateral ray of the bursa.

Sm.P. Sub-median head papilla.

$S p$. $\quad$ Spicule of male.

V.L. Ventral lip of the genital cone.

Vu. Vulva of female.

Vv. Ventro-ventral ray of the bursa. 